Primljen / Received: 31.10.2013. Ispravljen / Corrected: 18.5.2014.

Prihvaćen / Accepted: 4.6.2014. Dostupno online / Available online: 10.7.2014

\title{
Physicochemical characterization of cement treated kaolin clay
}

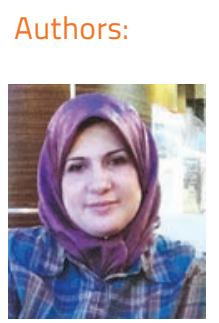

Khitam Abdulhussein Saeed, PhD. CE University of Technology Malaysia Faculty of Civil Engineering Department of Geotechnical Engineering University Al-Mustansiriyah in Bagdad khitamhussein@yahoo.com

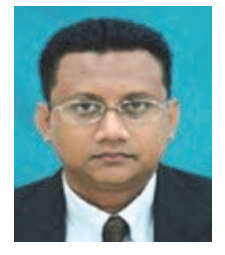

Prof. Khairul Anuar Kassim, PhD. CE University of Technology Malaysia Geotechnical \& Transportation Department Research Management Centre (RMC) kanuar@utm.my

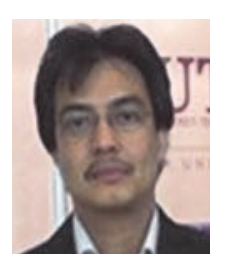

Prof. Hadi Nur, PhD. Chem University of Technology Malaysia Faculty of Civil Engineering Department of Geotechnical Engineering Ibnu Sina Institute for Fundamental Science Studies hadinur@utm.my
Scientific paper - Preliminary note

Khitam Abdulhussein Saeed, Khairul Anuar Kassim, Hadi Nur

\section{Physicochemical characterization of cement treated kaolin clay}

The physicochemical characterization of the cement-treated brown kaolin clay is presented in this paper. The effect of cement on the strength and compressibility of clay samples, at different curing times and cement contents, is investigated. Laboratory tests including compaction, unconfined compressive strength, and one-dimensional consolidation oedometer tests, were carried out on clay samples mixed with $5 \%$ and 10 $\%$ of cement. Long-term strength and compressibility test results point to an increase in the unconfined compressive strength and decrease in the compression index.

Key words:

kaolin, tropical soil, Portland cement, unconfined compressive strength, physicochemical behaviour

Prethodno priopćenje

Khitam Abdulhussein Saeed, Khairul Anuar Kassim, Hadi Nur

\section{Fizikalno-kemijska karakterizacija kaolinske gline s dodatkom cementa}

U ovom radu je predstavljena fizikalno-kemijska karakterizacija smeđe kaolinske gline s dodatkom cementa. Istražuje se utjecaj cementa na čvrstoću i stišljivost glinenih uzoraka uz variranje vremena njege i količine cementa. Na glinenim uzorcima s dodatkom 5 i 10 posto cementa obavljena su laboratorijska ispitivanja zbijenosti, jednoosne tlačne čvrstoće i jednodimenzionalne konsolidacije pomoću edometra. Rezultati ispitivanja čvrstoće i stišljivosti, provedenih tijekom dužega razdoblja, upućuju na porast jednoosne tlačne čvrstoće te na smanjenje indeksa stišljivosti.

Ključne riječi:

kaolin, tropsko tlo, portland cement, jednoosna tlačna čvrstoća, fizikalno-kemijsko ponašanje

Vorherige Mitteilung

Khitam Abdulhussein Saeed, Khairul Anuar Kassim, Hadi Nur

\section{Physikalisch-chemische Charakterisierung von Kaolin-Ton mit Zementzusatz}

In dieser Arbeit ist die physikalisch-chemische Charakterisierung von braunem KaolinTon mit Zementzusatz dargestellt. Der Einfluss von Zement auf die Festigkeit und Kompressibilität von Erdproben ist für verschiedene Aushärtungszeiten und Zementgehalte untersucht. Laborversuche sind an Proben mit 5 bis 10 Prozent Zementzusatz durchgeführt worden, um Verdichtung, einachsige Druckfestigkeit und eindimensionale Kompression durch Ödometer-Versuche zu ermitteln. Die Resultate bezüglich des Festigkeits- und Kompressibilitätsverhaltens weisen langfristig auf das Anwachsen der einachsigen Druckfestigkeit und die Reduzierung des Kompressibilitätsindex.

Schlüsselwörter:

Kaolin, tropische Böden, Portlandzement, einachsigen Druckfestigkeit, Physikalisch-chemisches Verhalten 


\section{Introduction}

Tropical clay soils are normally associated with volumetric changes when subjected to changes in water content due to seasonal water fluctuations. Kaolinite clays are among the soils that are affected by these problems. The minerals are formed under tropical weathering conditions in areas where precipitation is relatively high, and where drainage is good, which enables leaching of cations and iron from acidic granitic rocks [1]. As a result, kaolin deposits are considered to have poor engineering characteristics, exhibiting expansive properties, high plasticity, poor workability, and low shear strength. This may cause severe damage to civil engineering structures and facilities. Hence, these soils must be treated prior to construction operations, so that desired properties can be achieved. In such problematic clays, chemical stabilization techniques have proven to be effective [2].

The chemical stabilization of clays using cement is a common method that can be used to improve properties of soil to provide a workable platform for construction projects [3]. Cement is often used as an additive to improve the strength and stiffness of soft clayey soils, as stated by many authors [4-9]. They indicate that mixing cement into the soil leads to formation of a new structure within the soil grain accumulation. In this paper, the term structure refers to the cementing materials resulting from pozzolanic reactions.

According to European standard EN197-1 [10], "Portland cement clinker is a hydraulic material which shall consist of at least two-thirds by mass of calcium silicates (3CaO $\mathrm{SiO}_{2}$ and $2 \mathrm{CaO} \cdot \mathrm{SiO}_{2}$ ), the remainder consisting of aluminiumand iron-containing clinker phases and other compounds". Table 1 presents a typical chemical composition of Portland cement, while Table 2 presents components of Portland cement. The chemical composition is expressed in terms of oxides. The substances are actually present in the form of compounds known as clinker minerals. The most important clinker minerals in Portland cement are: alite, bellite, aluminate, and aluminate-ferrite [11]. These four main constituents (as given in Table 2) are the major strengthproducing components.

Table 1. Typical Composition of Portland cement [12]

\begin{tabular}{|c|c|}
\hline Oxide & Contents [\%] \\
\hline $\mathrm{CaO}$ & $60-70$ \\
\hline $\mathrm{SiO}_{2}$ & $17-25$ \\
\hline $\mathrm{Al}_{2} \mathrm{O}_{3}$ & $2-8$ \\
\hline $\mathrm{Fe}_{2} \mathrm{O}_{3}$ & $0-6$ \\
\hline $\mathrm{MgO}$ & $0-6$ \\
\hline $\mathrm{SO}_{3}$ & $1-4$ \\
\hline $\mathrm{K}_{2} \mathrm{O}$ & $0,2-1,5$ \\
\hline $\mathrm{Na}_{2} \mathrm{O}$ & $0,2-1,5$ \\
\hline
\end{tabular}

Table 2. Components of Portland cement

\begin{tabular}{|c|c|c|}
\hline Name & Abbreviation & Chemical formula \\
\hline Tricalcium silicate & $\mathrm{C}_{3} \mathrm{~S}$ & $3 \mathrm{CaO} \cdot \mathrm{SiO}_{2}$ \\
\hline Dicalcium silicate & $\mathrm{C}_{2} \mathrm{~S}$ & $2 \mathrm{CaO} \cdot \mathrm{SiO}_{2}$ \\
\hline Tricalcium aluminates & $\mathrm{C}_{3} \mathrm{~A}$ & $3 \mathrm{CaO} \cdot \mathrm{Al}_{2} \mathrm{O}_{3}$ \\
\hline Tetracalcium alumina-ferrite & $\mathrm{C}_{4} \mathrm{AF}$ & $4 \mathrm{CaO} \cdot \mathrm{Al}_{2} \mathrm{O}_{3} \mathrm{Fe}_{2} \mathrm{O}_{3}$ \\
\hline
\end{tabular}

The fundamental mechanism of soil cement stabilization has been outlined by many researchers [6, 13-16]. In general, mixing cement with water initiates chemical reaction named hydration, through which a hard cement paste is formed. When the pore water from soil encounters the cement, the hydration reaction of cement compounds $\left(C_{3} S\right)$ and $\left(C_{2} S\right)$ occurs rapidly. Calcium ions are rapidly released into solution, and hydroxide ions form, which causes the rise in $\mathrm{pH}$ value. The reaction rate, and hence the strength gain, are mainly controlled by; the ratio of $\mathrm{C}_{3} \mathrm{~S}$ to $\mathrm{C}_{2} \mathrm{~S}$ (where $\mathrm{C}_{3} \mathrm{~S}$ gives a rapid-hardening cement, while $\mathrm{C}_{2} \mathrm{~S}$ gives a cement that reacts slowly), the fineness of the grind, and the temperature.

The primary cementitious products resulting from the process of cement hydration are: hydrated calcium silicates $\left(\mathrm{C}_{2} \mathrm{SH}_{x^{\prime}} \mathrm{C}_{3} \mathrm{~S}_{2}\right.$ $\left.\mathrm{H}_{\mathrm{x}}\right)$, hydrated calcium aluminates $\left(\mathrm{C}_{3} \mathrm{AH}_{\mathrm{x}^{\prime}} \mathrm{C}_{4} A \mathrm{H}_{\mathrm{x}}\right)$, and hydrated lime $\mathrm{Ca}(\mathrm{OH})_{2}$. The first two cementitious products are primary cementitious products, while the hydrated lime is deposited as a separate crystalline solid phase. Cement particles bind the adjacent cement grains together during hardening, and form a hardened skeleton matrix, which encloses unaltered soil particles. In addition, the hydration of cement leads to the rise of the pore water $\mathrm{pH}$ value, which is caused by the dissociation of hydrated lime $\left(\mathrm{OH}^{-}\right.$ions in particular). The strongest bases react with the soil silica and alumina (which are inherently acidic), both from the clay minerals and amorphous materials on the clay-particle surfaces, in a manner similar to the reaction between weak acid and a strong base.

The secondary cementitious products occur when the hydrous silica and alumina gradually react with the calcium ions liberated from the hydrolysis of cement, to form insoluble compounds that harden when cured to stabilize the soil. This secondary reaction is known as the pozzolanic reaction. The reactions that take place in the soil-cement stabilization can be represented in form of equations (1),(2),(3), and (4). These reactions are related to the tricalcium silicate $\left(C_{3} S\right)$ only, because it is the most important constituent of Portland cement.

$$
\begin{aligned}
& \mathrm{C}_{3} \mathrm{~S}+\mathrm{H}_{2} \mathrm{O} \rightarrow \mathrm{C}_{3} \mathrm{~S}_{2} \mathrm{H}_{x} \text { (hydrated gel) }+\mathrm{Ca}(\mathrm{OH})_{2} \\
& \mathrm{Ca}(\mathrm{OH})_{2} \rightarrow \mathrm{Ca}^{++}+2(\mathrm{OH})^{-} \\
& \mathrm{Ca}^{++}+2(\mathrm{OH})^{-}+\mathrm{SiO}_{2} \text { (silicon dioxide) } \rightarrow \mathrm{CSH} \\
& \mathrm{Ca}^{++}+2(\mathrm{OH})^{-}+\mathrm{Al}_{2} \mathrm{O}_{3} \text { (aluminium oxide) } \rightarrow \mathrm{CAH}
\end{aligned}
$$


This paper further discusses the development of engineering behaviour of the cement-treated kaolin clay and its relation to the changes in microstructure.

\section{Materials}

The soil used for this study is a pure slightly acidic brown kaolin. The bulk soil was purchased from Tapah, which is located in the west portion of the Malay Peninsula. The Atterberg limits, grain size distribution, specific gravity, and the $\mathrm{pH}$ value of the kaolin, were determined in laboratory according to British Standard (BS,1377). Physical properties and chemical composition of this soil are shown in Table 3.

The ordinary Portland cement was used as stabilizer in this study. Due to its cost effectiveness and availability, it is considered to be the most widely used binder for stabilisation purposes [17].

Table 3. Physical properties and chemical composition of kaolin clay

\begin{tabular}{|l|c|}
\hline Parametar & Velue \\
\hline CEC - Cation-Exchange Capacity & $19,2[\mathrm{meq} / 100 \mathrm{~g}]$ \\
PH-value (L/S = 2.5) & 4,34 \\
Specific Gravity & $2,65\left[\mathrm{~kg} / \mathrm{m}^{3}\right]$ \\
Liquid Limit, LL & $40,8[\%]$ \\
Plastic Limit, PL & $22,6[\%]$ \\
Plasticity Index, PI & $18,2[\%]$ \\
BS Classification & $\mathrm{Cl}$ \\
ICL - Intrinsic Compression Line & $3[\%]$ \\
Maximum Dry Density & $1,5\left[\mathrm{Mg} / \mathrm{m}^{3}\right]$ \\
Optimum Moisture Content & $24,3[\%]$ \\
Unconfined Compressive Strength & $130[\mathrm{kPa}]$ \\
\hline
\end{tabular}

\section{Experimental program}

Both untreated and treated kaolin were subjected to similar laboratory tests in order to investigate the effect of cement on physicochemical and engineering properties. These tests included the compaction test, the unconfined compressive strength test (UCS), the one-dimensional consolidation odometer test, and also micro-structural tests such as the $\mathrm{X}$-ray diffraction, the energy-dispersive X-ray spectrometry (EDAX), the field emission scanning electron microscopy (FESEM), and the $\mathrm{pH}$ value measurements.

The microstructure of cement-treated kaolin clay was first examined using the x-ray diffraction and the field emission scanning electron microscopy. The grain and pore sizes of the cement-treated soil matrix were then examined and explained in terms of soil-cement reactions and induced microstructures. Finally, the changes in strength and compressibility of the cement-treated soil were examined and clarified through microstructure analysis.

\subsection{Sample preparation}

Clause 3.3.4.1 of BS 1377: Part 4: 1990 was adopted to determine the standard compaction characteristic in this study. This was achieved by compacting the soil in three equal layers in a 1 L Proctor mould, by applying 27 blows of the $2.5 \mathrm{~kg}$ rammer, which was dropped from the controlled height of $300 \mathrm{~mm}$. The moisture-density relationship curve was obtained for soil with different quantities of cement in order to investigate the effect of stabilizer on compaction parameters for clay soils.

The clay samples were first dried at $60^{\circ} \mathrm{C}$ before mixing. To prepare the cement-clay mixtures, the required amounts of dry kaolin were mixed with $5 \%$ and $10 \%$ of cement by weight of kaolin in the dry state, until an even distribution of cement in the mixture was obtained. The dry cement-clay mixtures were then mixed with distilled water. These mixtures were used for compaction tests. The moisture contents chosen for the present study corresponded to the optimum moisture content (OMC) of the treated and untreated kaolin determined from the compaction tests. These moisture contents were used for preparing the specimens for the unconfined compressive strength and consolidation tests.

According to the laboratory tests, an additional quantity of water ( $2 \%$ of the optimum wetness) was added to all design mixes to take into account the loss due to evaporation. All mixing was conducted within 10 min to avoid hardening of the clay-cement mixture. The mixture was then placed into a mould $(38 \mathrm{~mm}$ in diameter $\times 76 \mathrm{~mm}$ in length) under constant compactive effort as specified in BS1924: Part2: 1990 (Clause 4.1.5). Then the sample was removed by hydraulic jack, wrapped with a thin plastic film, and put in a plastic container with a tight lid to prevent any moisture loss during the curing time. The samples were then stored in a controlled-temperature room $\left(27 \pm 2^{\circ} \mathrm{C}\right)$ until the time required for testing for five curing periods, i.e., 7 days, 14 days, 28 days, 100 days, and 200 days. In order to ensure proper accuracy of results, three samples from each soil design mix were prepared for the five curing periods.

\section{Test Results and Discussion}

\subsection{Influence of cement on compaction properties}

Plots of the moisture-density relationship of the un-cemented and cemented samples compacted using the standard proctor energy are presented in Figure 1. As shown in that figure, an increase in cement content tends to result in a slight increase of the optimum moisture content (OMC). This suggests that the $\mathrm{OMC}$ is not significantly influenced by cement. On the other hand, the maximum dry density (MDD) increases with an increase in cement content. This is consistent with the study conducted by Horpibulsuk et al [18] where it is reported that the pores are classified into two categories: inter-aggregate pores (larger than $0.01 \mu \mathrm{m}$ ) and intra- aggregate pores (smaller than 0.01 $\mu \mathrm{m})$. During the clay and cement mixing, and with an increase in 
cement content, the formation of clay-cement clusters occurring due to physicochemical interaction, leads to reduction of the small inter-aggregate pore $(0.01-0.1 \mathrm{Im})$ volume, and to slight increase in the large inter-aggregate pore $(0.1-10 \mu \mathrm{m})$ volume, which results in the decrease of the dry unit weight. However with time, large inter-aggregate pores are filled due to the growth of cementitious products $[19,20]$. Thus, as a result of that, the total pore volume decreases with time. Therefore, an increase in the dry unit weight at $10 \%$ of cement can be observed.

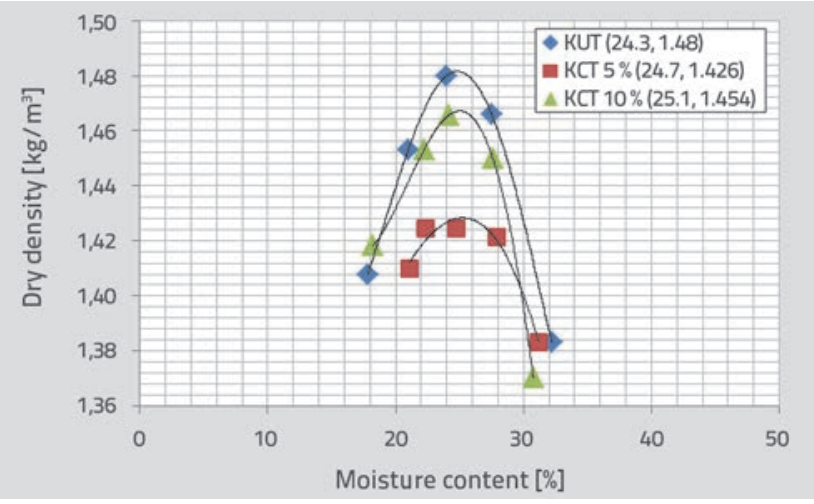

Figure 1. Variation of dry density with water content for kaolin clay soil samples stabilized by cement (KUT - Kaolin Untreated, KCT - Kaolin Cement Treated)

\subsection{Influence of curing time and cement content on unconfined compressive strength (UCS)}

Figures 2 and 3 reveal the effect of curing time progress and cement content on the development of UCS. It can be seen from Figure 2 that the UCS strength increases with an increase in curing time. This behaviour is attributed to the fact that the strength of the cement-treated clay is expected to increase with time as long as alkaline environment is present. That

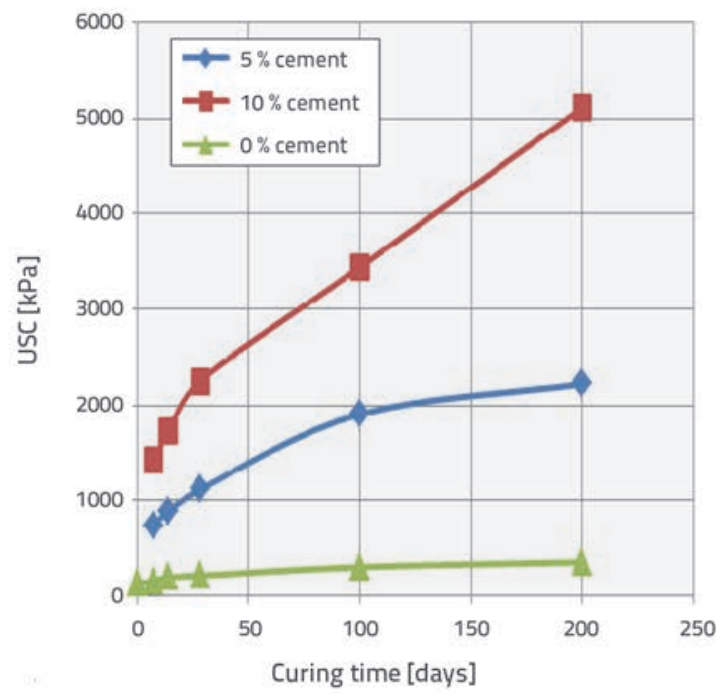

Figure 2. Effect of curing time on unconfined compressive strength (UCS) of cement-treated kaolin at different cement contents is due to the cement hydration, and the pozzolanic reaction can last for months or even years after mixing [15]. However, the strength increase range during 100 days and 200 days is different from strength values registered at early curing times $(7,14$, and 28 days). The early curing time of samples increases almost proportionately with the cement content throughout the range of cement content investigated. This is attributed to the completion of the secondary reaction for cement-soil. As a result, pozzolanic reactions are produced, and they form a hardened skeleton matrix, with unaltered soil particles.

The development of strength with an increase in cement content is shown in Figure 3. As a rule, the cement-treated soil exhibited the trend of UCS increase with an increase in cement content for all percentages of cement. As stated by Uddin et al. [8] and Chew et al. [9] ,the cementitious compounds of the treated clay increase with an increase in cement content. On the other hand, Kamruzzaman et al [21] and Uddin et al. [8] suggest that a minimum percentage of cement is also required to improve the strength of the untreated clay.

From the comparison between the two factors, it can beconcluded that the curing time influences the strength development more than the cement content. This is also in agreement with Nagaraj et al [19] and Uddin et al [8], where it is stated that the strength of the cement-treated clay soil increases with time. A relationship between the unconfined compressive strength, curing time ( $t$ ), and cement content (c) has been established by Mitchell [7], equ (5), as shown below:

$q u(t)=q u(t 0)+K \log (t / t 0)$

Where:

$q u(t)$ - unconfined compressive strength at $t$ days [kPa] qu (t0) - unconfined compressive strength at to days [kPa]

$\mathrm{K} \quad-480 \mathrm{c}$ for granular soil and 70c for fine-grained soils

C - cement content, $\%$ by mass

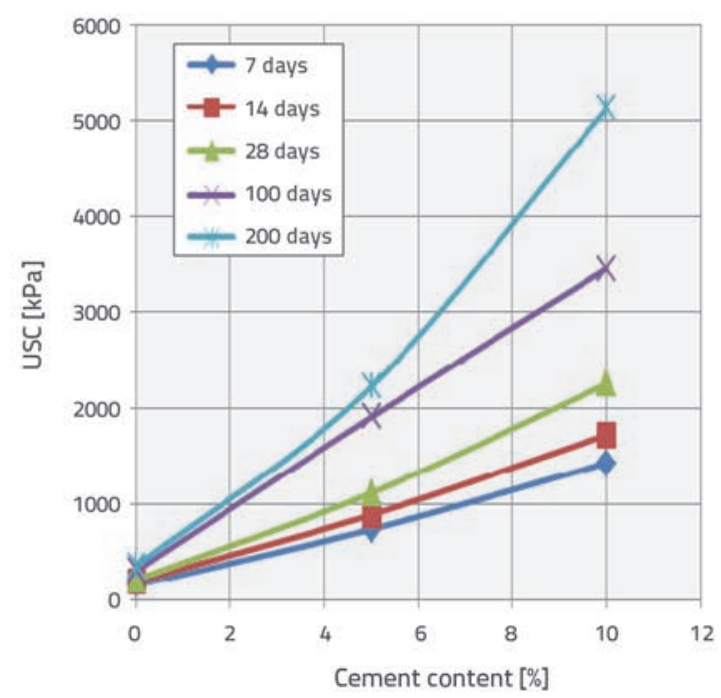

Figure 3. Effect of cement content on unconfined compressive strength (UCS) of cement-treated kaolin at different curing times 


\subsection{Influence of cement on compression index}

The compression index is an indication of compressibility of any soil. It is measured by means of the compression curve, e - log $\sigma^{\prime}$. Compression index is determined by the curve slope that indicates the compressibility of a normally-consolidated soil. Thus, if the compression index increases, the compressibility of that soil also increases [22].

Figure 4 shows the values of compression indexes at different cement contents, and at various curing times. This figure illustrates that there is a significant decrease in Cc values with an increase in the percentage of cement, which points to the tendency of soils treated with cement to resist compression. These results are consistent with the study prepared by $\mathrm{Ho}$ and Chan [23], who reported that the cement content can affect soil structure, and make the stabilized soil stiffer. Thus, the soil skeleton will be stronger when more cement is added because cement functions as a good stabilizer for soft clay.

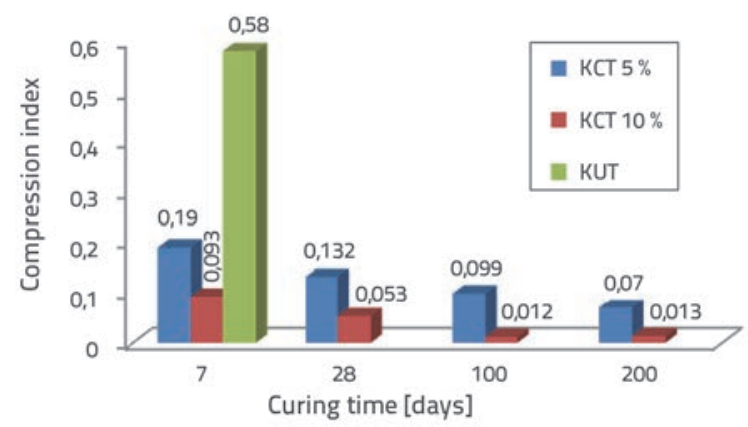

Figure 4. The variation of compression index values with cement content and curing time

\subsection{Micro-structural analysis}

\subsubsection{X-ray diffraction analysis}

In this study, the XRD powder was prepared to determine the presence of crystalline minerals in natural soil, and to monitor mineralogical changes caused by treatment. Samples for XRD testing were prepared by grinding the soil, using pestle and mortar, to a fine homogeneous powder. Then the sample was placed into an elliptical opening of an aluminium holder, and evenly distributed along the microscope slide until a smooth surface was achieved, as shown in Figure 5.

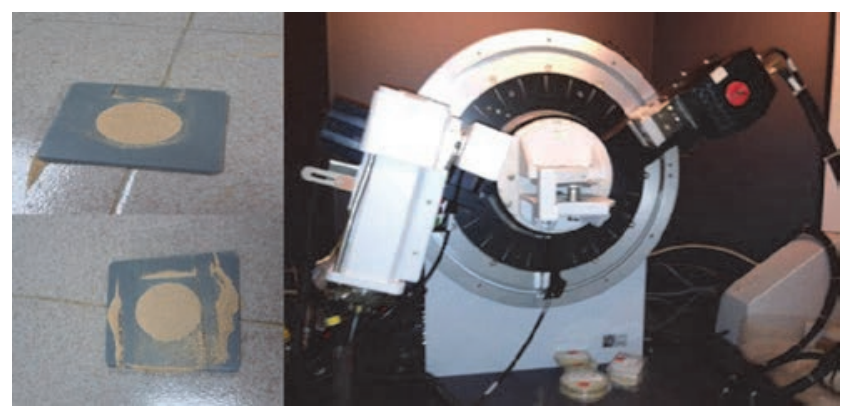

Figure 5. Preparation of powder samples for XRD-Diffraction
Figure 6 shows the XRD pattern of the untreated kaolin clay. The main mineralogical constituents of the untreated kaolin clay are the kaolinite $\mathrm{Al}_{2}\left(\mathrm{Si}_{2} \mathrm{O}\right)(\mathrm{OH})_{4^{\prime}}$ quartz $\mathrm{SiO}_{2^{\prime}}$ calcite $\mathrm{CaCO}_{3^{\prime}}$ and illite $\left(\mathrm{K}_{1} \mathrm{H}_{3} \mathrm{O}\right)\left(\mathrm{AL}_{2} \mathrm{Si}_{3} \mathrm{AlO}_{10}(\mathrm{OH})_{2}\right.$. As shown in the Figure, kaolinite is the predominant clay mineral.

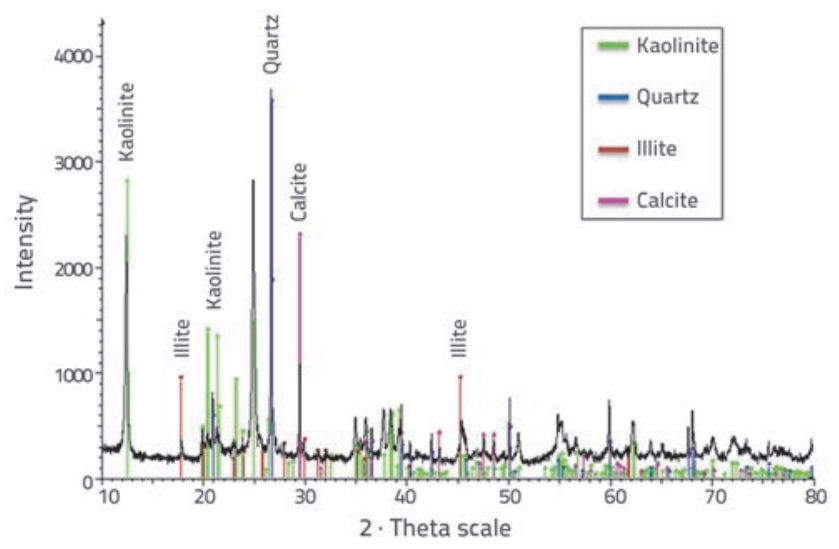

Figure 6. XRD of untreated kaolin clay soil

XRD-ray patterns of the untreated and the $10 \%$ cementtreated kaolin clay samples after 7, 100, 200 days are shown in Figure 7.

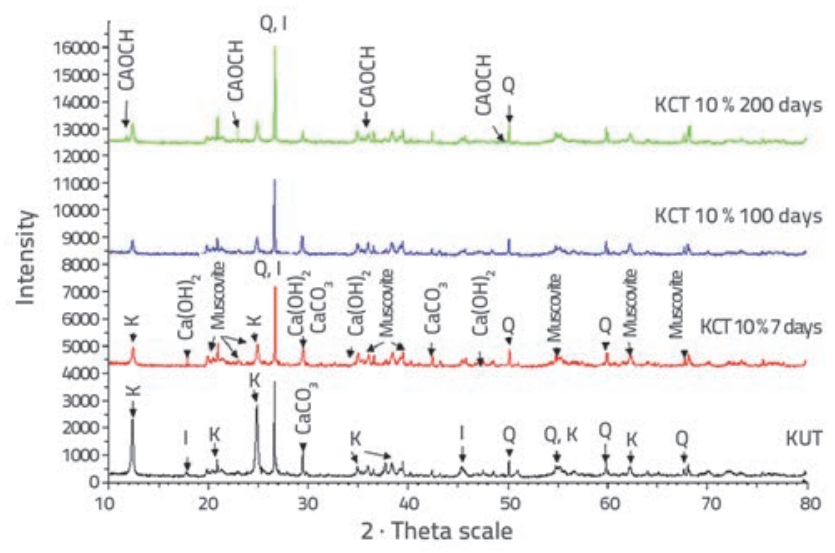

Figure 7. X-ray patterns for kaolin clay samples treated by $10 \%$ of cement for different curing times

$10 \%$ of cement content was chosen because it exhibits optimum cement content (OCC) for this study. As evident from the chemically-treated cement-containing samples, the kaolinite appears to have vanished at all curing times from cement-treated kaolin clay samples. This suggests that kaolinite is rapidly exhausted through pozzolanic reaction. This is consistent with high gain in strength when cement is added to the soft kaolin clay samples [24]. On the other hand, it can be noticed that illite minerals do not show a consistent trend of reduction with an increase in curing time. This suggests that illite is less involved in pozzolanic reaction than kaolinite, which is consistent with the findings reported by Porbahaetal et al [25], and Chew at al [26]. Moreover, a pozzolanic reaction that involves illite is 
much slower than the one involving kaolinite [24]. In such a case, higher cement content is needed to start pozzolanic reaction. As secondary cementitious products from the kaolinite-driven pozzolanic reaction are deposited onto the illite cluster surface, the cementitious products gradually encapsulate the clusters. Thus, this encapsulation protects illite from further attack by the cement, and no further pozzolanic reaction can occur.

Furthermore, a new compound was detected at cementtreated samples at 7 days. This compound is attributed to Portland $\mathrm{Ca}(\mathrm{OH})_{2}$ at $2 \theta$ of $18.2,34.5,47.4$. It is represented by one of the primary cementitious products, which result from the process of cement hydration as listed previously in the literature. In addition, Muscovite was detected at $2 \theta$ of $20,22.9,26.7,35$, which is the product of reaction between illite and clay mineral. Muscovite is a phyllosilicate mineral of aluminium and potassium. It can appear as a secondary mineral resulting from alteration of feldspar [27]. In addition, due to the presence of Calcite $\mathrm{CaCO}_{3^{\prime}}$ the monocarbonate hydrate $\left(\mathrm{Ca}_{4} \mathrm{Al}_{2} \mathrm{O}_{6} \mathrm{CO}_{3} \cdot 11 \mathrm{H}_{2} \mathrm{O}\right)$ formed at cement-treated kaolin samples cured for 200 days. This compound forms as a result of hydration of the cement paste $\left(\mathrm{C}_{3} \mathrm{~A}\right)$ with $\mathrm{CaCO}_{3}[28]$.

\subsubsection{Scanning electron microscope analysis}

The A JSM-6701F JEOL Field Emission Scanning Electron Microscope (FESEM) was used in this study to analyse morphological changes and topographic features associated with clay particles before and after treatment. Observations were also conducted using a scanning electron microscope equipped with an energy dispersive $X$-ray analyser (EDAX).

The samples were fully dried; all water had to be removed from samples because the water would vaporize in the vacuum. Then, samples were made conductive by coating them with a thin layer of conductive material. In this study, samples were coated with gold. This was done by using a device called "sputter coater" as shown in Figure 8.

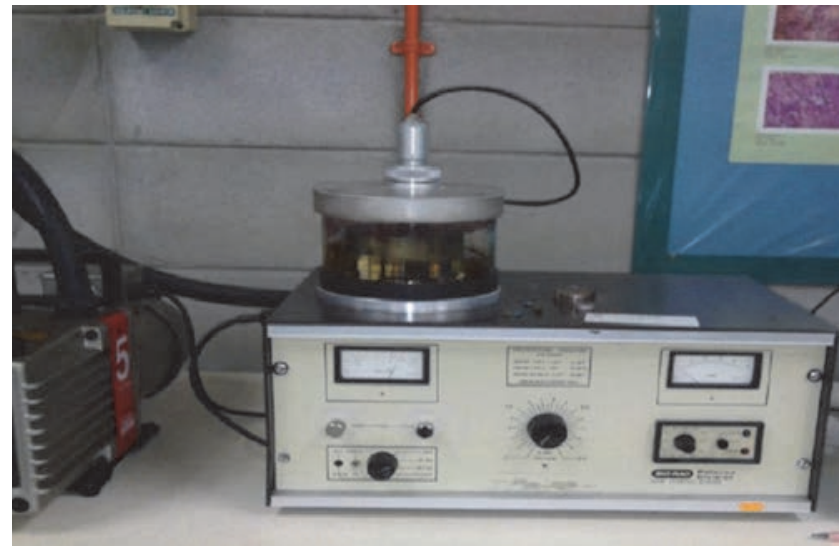

Figure 8. Gold sputter coater
The energy dispersive $x$-ray spectrometry was applied to identify elements present on the surface of clay particles. This method was also applied to monitor relative elemental changes induced by stabilizers through intensity of peaks at various time intervals.

The micrograph of natural kaolin clay is presented in Figure 9. It can be observed that the neatly arranged book-like kaolinite particles were the predominant feature of natural soil [29]. Kaolin generally has an aggregated and edge to-face and edge-to-edge flocculated structure [30].

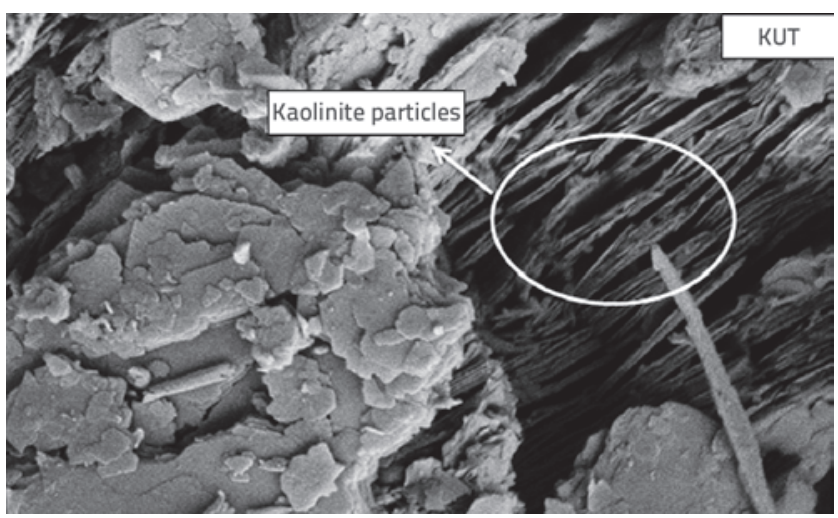

Figure 9. FESEM image of untreated kaolin clay soil at magnification of $X 10.000$

In the context of SEM photomicrographs of the cementtreated kaolin clay, Hwan et al [30] reported in their study that the cement can not be seen in the photomicrographs at low cement content. However, at OCC with $10 \%$ of cement, the presence of cement was evident throughout the materials. Figure 10 shows the effect of adding $10 \%$ of cement as stabilizer on the microstructure of kaolin clay specimens at different curing times ( 7 days, 100 days, and 200 days). As shown in Figure 10.a, the addition of cement results in an open structure with some signs of reticulation. By adding cement, clay particles are transformed from a flaky form into a flocculating structure. Also, the microstructure of the 7-day cement-treated specimens includes normally developed forms of main crystalline phases $\mathrm{Ca}(\mathrm{OH})_{2^{\prime}}$ as detected in the $\mathrm{XRD}$ results.

With the passing of time from 100 days to 200 days, as shown in Figures 10.b and 10.c, respectively, the flocculated morphology of the structure changes at the edges of clay particles. Furthermore, it can be noticed that sufficient cementing compounds become more evident due to the pozzolanic reaction. Thus, soil particles are coated and joined together making the voids in the soil less distinct [31]. In addition, the formation of white cementitious compounds on the surface of soil particles was observed at 100 and 200 days of curing time. The presence of these compounds influenced formation of further cementitious compounds at the long curing time. This is also consistent with the findings of Kassim et al [32]. 
EDAX spectrums of the untreated brown kaolin clay sample and cement-treated samples at different curing times are presented in Figure 11. As can be seen, high intensities of aluminium (Al), silicon (Si), followed by lower levels of potassium (K), iron (Fe), magnesium $(\mathrm{Mg})$, and carbon (C), are evident. The presence and intensities of these elements is consistent with the chemical composition of kaolinite [33]. On the other hand, time-dependent changes in the Al:Si and Ca:Si ratios of brown kaolin clay mix-designs are shown in Table 4. It can be noticed that the Al:Si content decreases with an increase in curing time. This behaviour suggests an increase in the silica present at the surface of clay particles due to dissolution of the coating. This is in agreement with findings made by Eisazadeh et al. [34]. However, at the 200-day curing time, the Al:Si ratio shows a relatively higher value. This is consistent with the mechanism by which compounds of aluminate hydrate gel are deposited on the surface of the particles. Furthermore, an increase in the Ca:Si ratio is related to the presence of Portland in the composition of cement.
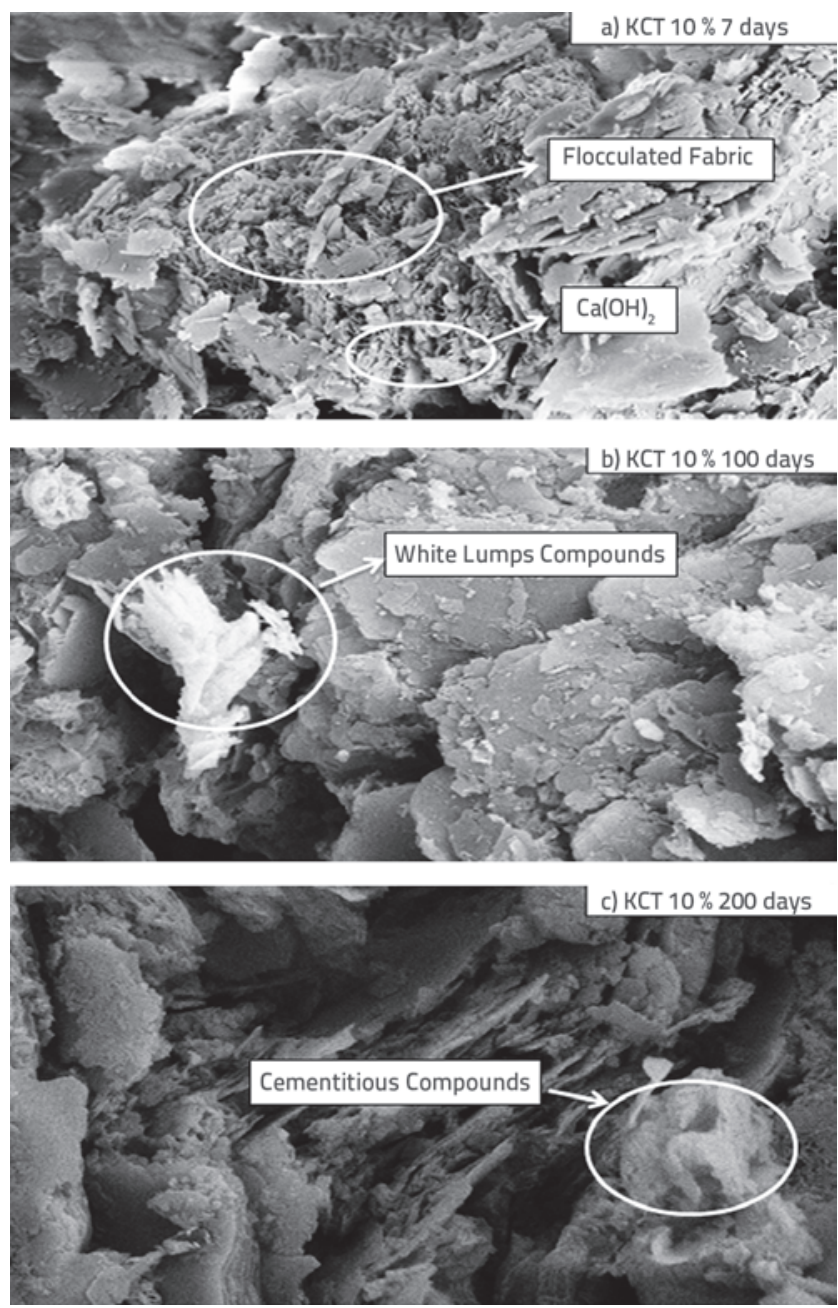

Figure 10. FESEM images of $10 \%$ cement treated brown kaolin clay after different curing times at magnification of $\mathrm{X} 10.000$
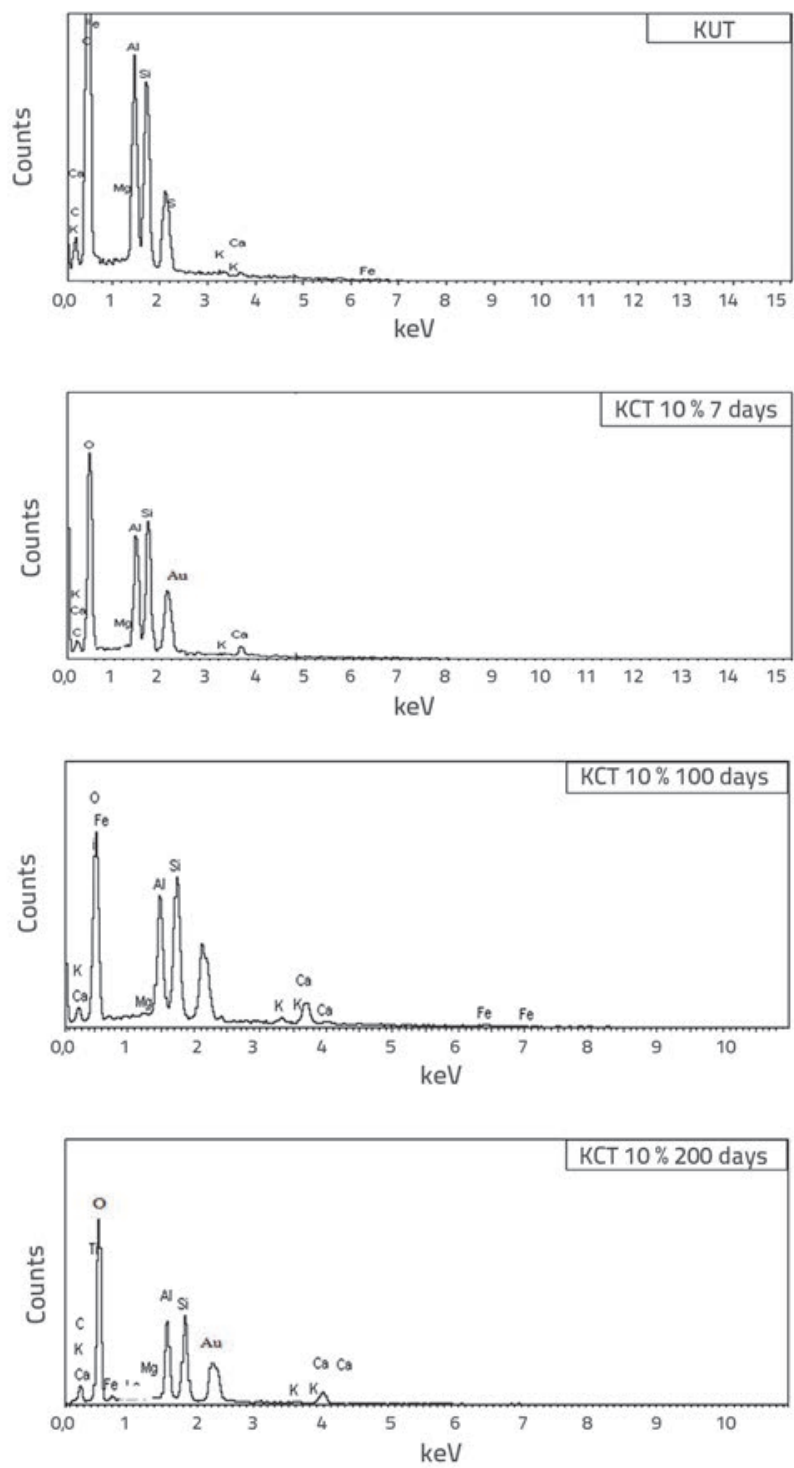

Figure 11. EDAX spectrums of untreated and $10 \%$ cement-treated brown kaolin samples after different curing times

Table 4. Variation of Al:Si and Ca:Si ratios for $10 \%$ cement treated brown kaolin samples at different curing times

\begin{tabular}{|c|c|c|c|}
\hline \multicolumn{2}{|c|}{ Sample description } & \multicolumn{2}{c|}{ Ratio [\%] } \\
\hline Mix design & $\begin{array}{c}\text { Curing time } \\
\text { [days] }\end{array}$ & Al / Si & Ca / Si \\
\hline KUT & - & 0,997 & 0,027 \\
\hline KCT10\% & 7 & 0,747 & 0,21 \\
\hline KCT10\% & 100 & 0,672 & 0,448 \\
\hline KCT10\% & 200 & 0,793 & 0,474 \\
\hline \multicolumn{2}{|l|}{ Note: K - Kaolin clay, UT - Untreated, CT - Cement treated } \\
\hline
\end{tabular}




\section{5. $\mathrm{pH}$ values}

The $\mathrm{pH}$ of a solution is a measure of the molar concentration of hydrogen ions in the solution, and it is a measure of the acidity or basicity of the solution. Furthermore, the $\mathrm{pH}$ value of a soil solution provides useful information on chemical reactions of soil, because it reflects the changes that occur in the medium. In addition, it should be noted that $\mathrm{pH}$ has a great effect on the stabilization process due to its influences on the distribution of charge on clay lattice. Therefore, it is considered as a controlling factor for solubility of clay minerals, as the cement-clay reaction will continue as long as the alkaline environment is preserved.

In this study, the $\mathrm{pH}$ measurement was performed using a Hannah model $\mathrm{HI} 8424 \mathrm{pH}$ meter. This device was used to measure the $\mathrm{pH}$ value for the cement-treated kaolin samples according to BS 1377: Part 3: 1990 (Clause 9.1). It was established that an average $\mathrm{pH}$ depends on the data that were obtained in triplicate.

The dependence of the $\mathrm{pH}$ value on cement content is presented in Figure 12. In this test, two percentages, namely $5 \%$ and 10 $\%$, were used to evaluate the influence of cement content with curing time on the variation of $\mathrm{H}_{3} \mathrm{O}^{+}$ion concentrations of pore water. As shown in Figure 12, the $\mathrm{pH}$ values for the $5 \%$ cement-treated kaolin clay samples increase with time. The rise in $\mathrm{pH}$ values may be related to the dissociation of $\mathrm{OH}^{-}$ions, produced during cement hydration, from $\mathrm{Ca}(\mathrm{OH})_{2}$. Furthermore, based on the hypothesis of cement reaction mechanism, the primary and secondary reactions must be distinguished in the clay - cement mixture. The hydrolysis and hydration of cement were the results of the primary reaction that led to the increase of the $\mathrm{pH}$ value for the pore water solution, as mentioned above.

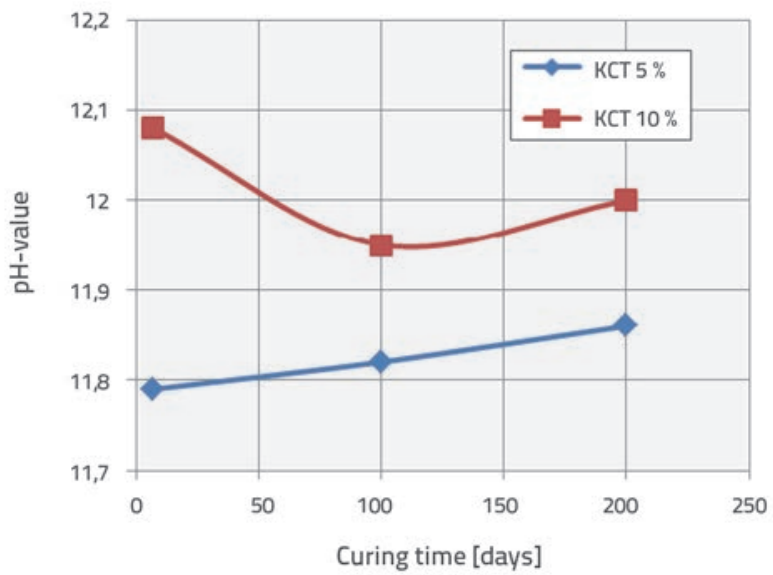

Figure 12. Variation of pH for the cement - brown kaolin mix design as a function of cement content and time

Figure 12 also shows an increase in the $\mathrm{pH}$ value with the rise in cement content $(10 \%)$. However, this $\mathrm{pH}$ value significantly decreases with time. This reduction in the $\mathrm{pH}$ value is attributed to the consumption of $\mathrm{OH}^{-}$ions during the cement-soil hardening due to pozzolanic reaction, because of the secondary reaction of cement-clay soil interaction. These findings are consistent with the study made by Hwan and Song [30].

\section{Conclusion}

Based on investigations conducted in this study, the following conclusions can be made:

- The addition of cement slightly increases the optimum moisture content. The dry density decreases at $5 \%$ cement, and then rises at $10 \%$ cement.

- The analysis of compressive strength data presented in this study reveals several interesting points regarding the time-dependent soil-cement reactions between different mineral types and ions introduced by cement stabilizer. The unconfined compressive strength of cement-treated samples increases with an increase in cement content and curing time factors. However, based on the comparison between the influences of both factors, the influence of the curing environment factor is more significant compared to cement content.

- The cement stabilization has a significant effect on the compressibility of treated soils. The cement content can affect the structuration of soil and make the stabilized soil stiffer. Thus, the soil skeleton will be stronger with higher cement content, which is a function of low compressibility of soils.

- Microstructural results reveal that chemical stabilizers preferentially attack the alumina surface of clay particles. Therefore, it would be reasonable to suggest that aluminate hydrate compounds are more likely to form with respect to cement treatment.

- Based on the data collected from the FESEM, it could be concluded that the primary ion-exchange reactions, followed by surface alteration of the clay structure, are the main mechanisms that are responsible for the improvement in cement-stabilized kaolin clay samples. Furthermore, the Ca/Si and Al/Si ratios, as obtained from EDAX analysis, suggest that significant changes occur in the surface composition of soil particle at different time intervals.

- Furthermore, the treatment by cement increases the level of flocculation due to the rise in $\mathrm{pH}$, and hence the electrolytic concentration of the soil pore water due to addition of cement.

\section{Acknowledgements}

This study was sponsored by Universiti Teknologi Malaysia (UTM).The authors are grateful to the technical staff of the Geotechnical Laboratory, Chemical Laboratory, and Environmental Laboratory of UTM for their assistance during the experiments. 


\section{REFERENCES}

[1] Mitchell, J. K., Soga, K.: Fundamentals of Soil Behavior. (3rd edition). New York: John Wiley and Sons, 2005.

[2] Ingles, O.G., Metcalf, J.B.: Soil stabilization - principles and practice. Melbourne: Butterworth,1972.

[3] Brandon, T., Brown, J., Daniels, W., DeFazio, T., Filz, G., Musselman, J., Forshaand, C., Mitchell, J.: Rapid Stabilisation/ Polymerization of Wet Clay soils, Literature Review, Air Force Research Laboratory, Blacksburg, 2009.

[4] Lee, S.L., Yong, K.Y.: Grouting in substructure construction, 9th Regional Conference on Soil Mechanics and Foundation Engineering, 2, pp. 41-49,1991

[5] Lacasse, S., Berre, T., Lefebvre, G.: Block sampling of sensitive clays, 11th International Conference on Soil Mechanics and Foundation Engineering, 2, pp. 887-892,1985.

[6] Lerouiel, S., Vaughan, P.R.: The general and congruent effects of structure in natural soils and weak rock, Geotechnique 40 (3), pp. 467-488, 1990

[7] Mitchell, J.K.: Soil improvement state of the art report, 10th International Conference on Soil Mechanics and Foundation Engineering 4, pp. 509-565,1981.

[8] Uddin, K., Balasubramaniam, A. S., Bergado, D.T.: Engineering behaviour of cement-treated Bangkok soft clay. Geotech. Eng., 2891, pp. 89-119, 1997.

[9] Chew, S.H., Lee, F.H., Lee, Y.: Jet grouting in Singapore marine clay. 3rd Asian Young Geotechnology Engineering Conf: pp. 231238, 1997.

[10] British Standards Institution, BS EN 197-1:2000, Cement-Part 1 : Composition, specifications and conformity criteria for common cements

[11] Lea, F. M.: The chemistry of cement and concrete. The University of Michigan: E. Arnold, 1956.

[12] Janz, M., Johansson, S.E.: The Function of Different Binding Agents in Deep Stabilization, Swedish Deep Stabilization Research Centre, Report No. 9, pp. 9-11, 2002.

[13] Schaefer, V.R., Abramson, L.W., Drumheller, J.C., Sharp, K.D.: Ground improvement, ground reinforcement and ground treatment: Developments 1987 to 1997., ASCE Geotech. Special Publication, GSP, 69, 1997.

[14] Chen, Q.Y., Tyrer, M., Hills, C.D., Yang, X.M., Carey, P.: Immobilization of heavy metals in cement-based solidification/ stabilization: A review. Journal of Waste Management, 29, pp. 390-403, 2009.

[15] Hassan, M.M.: Engineering Characteristics of Cement Stabilized Soft Finish Clay - A laboratory Study, Helsinki University of Technology: Ph.D Thesis, 2009.

[16] Kezdi, A.: Stabilized earth roads, Development in Geotechnical Engineering, Elsevier Scientific, New York, 2009.

[17] USEPA. Treatment technologies for site cleanup: Annual from http://www.epa.gov, 2004

[18] Horpibulsuk, S., Rachan, R., Chinkulkijniwat, A., Raksachon, Y., Suddeepong, A.: Analysis of strength development in cementstabilized silty clay from microstructural considerations, Construction and Building Materials, 24, pp. 2011-2021, 2010.
[19] Nagaraj, T.S., Vatasala, A., Srinivasa, M.: Discussion on "Change in pore size distribution due to consolidation of clays" by F.J. Griffith and R.C. Joshi. Geotechnique 40 (2), pp. 303-305,1990.

[20] Mitchell, J. K.: Fundamentals of soil behaviour. John Wiley \& Sons, Inc., 422, 1976.

[21] Kamruzzaman, A.H.M., Chew, S.H., Lee, F.H.: Behaviour of soft Singapore marine clay treated with cement, ASCE Geotech. Special Publication, GSP, 113, pp. 472-485, 2001.

[22] Stalin, V.K.: Behaviour of lime-fly ash-sand-clay mixed columns in the improvement of soft ground, in Ground improvement techniques (ed. H.A. Faisal) 4th International Conference on Ground Improvement Techniques, Kuala Lumpur, Malaysia, 26 - 28 March 2002, (2) pp. 701-706, 2002.

[23] Ho, M.H., Chan, C.M.: Some Mechanical Properties of Cement Stabilized Malaysian Soft Clay. World Academy of Science, Engineering and Technology, 2011.

[24] Eades, J.L., Grim, R.E.: Reactions of hydrated lime with pure clay minerals in soil stabilization. High. Res. Bull, 262, pp. 51-63, 1960.

[25] Porbaha, A.; Shibuya, S., Kishida, T.: State of the art in deep mixing technology. Part III: Geomaterial characterization." Ground Improvement, 4(3), pp. 91-110, 2000.

[26] Chew, S., Kamruzzaman, A., Lee, F.: Physicochemical and Engineering Behavior of Cement Treated Clays. J. Geotech. Geoenviron. Eng., 130 (7), pp. 696-706, 2004.

[27] Rickwood, P. C.: Muscovite mineral information and data mineral, American mineralogist, 66, pp. 885-907, 1981.

[28] Kakali, G., Tsivilis, S., Aggeli, E., Bati, M.: Hydration products of C3A, C3S and Portland cement in the presence of CaCO3. Cement and Concrete Research, 30, pp. 1073-1077, 2000.

[29] Mitchell, J.K., Dermatas, D.: Clay soil heave caused by limesulfate reactions. Innovations in uses for lime, American Society for Testing and Materials, Philadelphia. pp. 41-64, 1992.

[30] Hwan, K., Song, L.: Mechanical Properties of Weakly Bonded Cement Stabilized Kaolin. KSCE Journal of civil engineering, 6, No. 4, pp. 389-398, 2002.

[31] Muhmed, A., Wanatowski, D.: Effect of Lime Stabilisation on the Strength and Microstructure of Clay. IOSR Journal of Mechanical and Civil Engineering (IOSR-JMCE), 6, Issue 3, pp. 87-94, 2013.

[32] Kassim, K.A.: The Nanostructure Study on the Mechanism of Lime Stabilised Soil, Research Vot No: 78011, Department of Geotechnics and Transportation, Universiti Teknologi Malaysia, 2009.

[33] Carroll, D., Starkey, H.C.: Reactivity of clay minerals with acids and alkalies. Clays and Clay Minerals,19, pp. 321-333, 1971.

[34] Eisazadeh, A., Kassim, K. A., Nur, H.: Stabilization of tropical kaolin soil with acid and lime. Journal of Nat. Hazards, 61, pp. 931-942, 2012 